\title{
STUDENTS' DIFFICULTIES IN WRITING DESCRIPTIVE TEXT AT THE SEVENTH GRADE OF SMP SINT CAROLUS BENGKULU
}

\author{
NELLY KRISTIANA \\ University of Bengkulu \\ nelly.tarkibkl@gmail.com \\ WISMA YUNITA \\ University of Bengkulu \\ wismayunita@unib.ac.id \\ SYAHRIAL \\ University of Bengkulu \\ eric.syahrial@gmail.com
}

DOI: 10.29300/ling.v7i1.4249

Received: March $9^{\text {th }}, 2021$

Accepted: June $8^{\text {th }}, 2021$

Published: July $14^{\text {th }}, 2021$

\begin{abstract}
The objective of this research was to investigate the students' difficulties in writing descriptive text, the most dominant difficulty faced by the students, and the students' strategies to overcome these difficulties. This study was conducted at the Seventh Grade of SMP Sint Carolus Bengkulu. This is a descriptive quantitative study. The instruments used in this research were questionnaire and interview. Based on the results, it was found that students experienced difficulties in the three aspects of the study, namely linguistic, psychological, and cognitive difficulties. In each of these aspects, organization is the highest one followed by behaviour, feedback, grammatical items, and vocabulary. In organizations, difficulties in developing ideas are the most difficult. Anxiety is the highest difficulty in behaviour, while the lack of practice is the most difficulty in the feedback. The difficulty in using connectors is the highest point in the grammatical items, and the lack of vocabulary is the most difficulty in the vocabulary. Based on the questionnaire and interview results, organization was the most difficult aspect in writing descriptive text. To overcome the difficulties, the students choose to master vocabulary and learning from other sources such as books or the internet while the others like to read from dictionary. Finally, it is also suggested for other researchers to carry out similar research in a broader scope, as well as a description, especially about the mechanic that get negative results.
\end{abstract}

Keywords: Descriptive text, difficulty, writing

\section{INTRODUCTION}

Writing is one of language skills which is important for the students to acquire well in order to master English. Not only has writing significant role especially for communicating in society, the ability to write has become an important skill in students' life. It is the fact that almost every activity of the daily life of students is done in written forms, such as doing exercises, homework, and final examination (Dastgeer \& Afzal, 2015). Skilled writers use

How to cite this article: Kristiana, N., Yunita, W., \& Syahrial, S. (2021). Students' Difficulties in Writing Descriptive Text at the Seventh Grade of SMP Sint Carolus Bengkulu. Linguists : Journal Of Linguistics and Language Teaching, 7(1), 67-76. doi:http://dx.doi.org/10.29300/ling.v7i1.4249 
strategies to plan, write, and revise their compositions, as well as strategies to self-regulate performance (Swanson, Harris \& Graham, 2003).

Despite of its importance, writing is not an easy skill to be mastered, especially if the writing itself has to be written in another language but the mother tongue. Tarigan (1994) stated that using English as a foreign language is different with first and second. But it is just different in environmental using but a language is still a language. Teaching English for foreign language is teaching English in general. So, even in the country who uses English as foreign language the goal is still that English is an international language. They can communicate and use English in general and internationally (Oshima and Hogue, 1997).

In this case, writing in English can be troublesome for students as English is not the first language in this country, not even a second language, yet a foreign language. Harmer (2007) argues that lack of knowledge about the writing process, experiencing difficulties in generating topics and ideas, do little planning, lack strategies for producing and organizing text, have difficulties with the mechanics of writing, and engage in little or no revision, make writing becomes even more difficult ability to be mastered by the students.

According to Bryne (1997), there are three major categories which make writing difficult namely Linguistics (language use and vocabulary), Psychology (content aspect), and Cognitive difficulty (organization and mechanics). Linguistics difficulties are about grammar, vocabulary, language use and choice of sentence. The physiology difficulties are about writer's difficulty because there aren't direct interaction and feedback from the reader when they are writing. Finally, cognitive difficulties are about spelling, punctuation, capitalization and paragraphing.

Based on the observation done at Sint Carolus English Junior High school, there are some problems found in teaching writing. It is found that the students' score which is still low . The English teacher claimed that the students were lack of vocabulary and writing ungrammatically. This agrees with the research conducted by Millah (2015) which states that there are some obstacles in the face in writing include: lack of knowledge about the process of writing, the difficulty in generating topics and ideas, least of planning, lack of strategy to produce and organize text, experiencing difficulties with writing mechanism.

There are several studies that have been conducted regarding on students' difficulties on writing descriptive text. Rianto (2017) found that the students' difficulties in writing are the grammatical skill, vocabulary mastery, and expressing idea. Aji (2016) pointed that there are nine difficulties in writing descriptive text that were supporting sentences, developing ideas, main idea, lack of vocabulary, grammar, lack of sources, arrangement, coherent and cohesion and diction. Same line with it, Hanafi (2013) argued that the students' difficulties in 
writing descriptive text are generic structure of descriptive text consist of describing object in detail and grammar mastery such as simple present tense, lack of vocabulary and enable to write correct spelling words, and lack of creativity.

Based on the explanation above, it was found that writing is an essential skill for students to be mastered but they have some difficulties in doing that especially in writing descriptive text. So, it is important to investigate these phenomena. This study aimed to investigate; (1) What are the students' difficulties in writing descriptive text at the seventh grade of SMP Sint Carolus Bengkulu? (2) What is the most dominant difficulty faced by the students in writing descriptive text? (3) How do the students overcome these difficulties?

\section{METHOD}

This study employed descriptive quantitative method. Sugiyono (2012) explained that descriptive research is a study conducted to determine variables, either the variable is one or even more without making comparison or connect with other variables. Quantitative methods emphasize objective measurements and the statistical, mathematical, or numerical analysis of data collected through polls, questionnaires, and surveys, or by manipulating preexisting statistical data using computational techniques.

\section{Respondents}

The subject of this research was the seventh-grade students at SMP Sint Carolus Bengkulu. There were 125 students which is separated into 4 classes, consist of 57 female students and 68 male students.

\section{Instruments}

The instruments used in this study were questionnaire and interview. The questionnaire consisted of three major aspects, namely linguistic, psychology, and cognitive difficulties. Each aspect contains 2 sub-aspects which contain 5 statements of each. The students need to choose options which are Strongly Agree (SA), Agree (A), Disagree (D), and Strongly Disagree (SD). The interview consisted of five open-ended questions. The interview questions aimed to take depth knowledge of the difficulties. 


\section{Data analysis}

The scale responses to the questionnaire were calculated by using some formulas. To answer the research questions, the researcher used scale regarding the percentage score and analyzed by using interval score.

$$
\mathrm{P}=\frac{F}{N} \mathrm{X} 100 \%
$$

Where:

$$
\begin{aligned}
& \mathrm{P}=\text { Percentages } \\
& \mathrm{F}=\text { Frequency of answer } \\
& \mathrm{N}=\text { Total of frequency }
\end{aligned}
$$

$P$ in this formula means the result of percentage $(\%), f$ means the frequency of the samples, and $n$ means the total number of the whole samples. In addition, the following formula is purposed to find interval.

$$
i=\frac{H-L}{K}
$$

Where:

i : Interval

$\mathrm{H} \quad$ : The high score value

$\mathrm{K} \quad$ : The total number of categories

L : The low score value

The value of high score was 400, and the lowest was 125 . It was gained by multiplying $4 \times 125(4=$ the high score of categories, $125=$ the total number of correspondents), and the lowest score was gained by multiplying 1 x 125 ( 1 = the lowest score of categories, $125=$ the total number of correspondents). So, the interval for determining the category was 93.75. The interval then was divided with total number participant which was 125 so it was 0.75 . After that, the students mean score starts to be classified into very positive, positive, negative, and very negative.

Table 1. The Classification of Students' Difficulties

\begin{tabular}{|c|c|c|}
\hline No. & Range & Category \\
\hline 1. & $3.25-4$ & Very positive \\
\hline 2. & $2.5-3.24$ & Positive \\
\hline 3. & $1.75-2.4$ & Negative \\
\hline 4. & $1-1.74$ & Very negative \\
\hline
\end{tabular}




\section{FINDINGS AND DISCUSSION}

\section{Findings}

\section{Students' Difficulties in Writing Descriptive Text}

The result of this research can be seen in the table below

Table 2. Students' Difficulties in Writing Descriptive Text

\begin{tabular}{|c|c|c|c|c|}
\hline Aspects & Sub-Aspects & Mean & Category & Total \\
\hline \multirow{2}{*}{ Linguistic } & Grammatical items & 2.57 & Positive & \multirow{3}{*}{$\begin{array}{c}\text { Positive }=5 \\
(83.33 \%)\end{array}$} \\
\hline & Vocabulary & 2.52 & Positive & \\
\hline \multirow{2}{*}{ Psychology } & Behavior & 2.60 & Positive & \\
\hline & Feedback & 2.58 & Positive & \multirow{3}{*}{$\begin{array}{c}\text { Negative }=1 \\
(16.67 \%)\end{array}$} \\
\hline \multirow{2}{*}{ Cognitive } & Organization & 2.65 & Positive & \\
\hline & Mechanic & 2.39 & Negative & \\
\hline
\end{tabular}

The finding of this research shows that the mean score of the grammatical items was 2.57 which means that there was a positive respond toward students' difficulties in writing descriptive text. In addition to the vocabulary, the mean score of all items was 2.52 which means that there was positive respond toward difficulties in vocabulary aspect. For behavior, the mean score of whole items was 2.60 which also means that there was positive respond from the students. In the feedback, the mean score all of items was 2.58 which means there was positive respond from the students. The mean score of organization aspect was 2.65 which means there was positive respond from the students. However, the mean score of mechanic aspect was 2.39 which mean that there was negative respond from the students.

Based on the explanation above, there were five aspects which received positive respond from the students toward the difficulties in writing descriptive text. On the other hand, there was a negative respond toward the difficulties in mechanic which contradicted with the result of organization in the cognitive aspects. In summarizing, the seventh-grade students of SMP Sint Carolus Bengkulu had difficulties in writing descriptive text. Furthermore, each of the aspect is described more in the detailed explanations.

\section{The Most Dominant Difficulty Faced by the Students}

Based on the result, it was found that the most difficult aspect in writing descriptive text for seventh grade students of SMP Sint Carolus Bengkulu was the organization. It was found from the mean score of organization sub-aspect items was 2.65 which is the highest among the other aspects. It is also confirmed by the result of interview which showed that the most difficult aspect in writing is when the students choosing and arranging words into a meaningful sentence. The students have difficulty in writing from looking the idea of writing 

to the execution the idea. Organizing and developing ideas seems the bigger difficulties compare to other indicators.

\section{Students' Strategies to Overcome these Difficulties}

The interview result shows the strategies the students use to overcome the problem they faced in writing. The result suggest that vocabulary mastery is very important in order to improve their writing. It can be done by practicing over and over again. For some, they practice by reading some examples of descriptive text from other sources such as books or internet. The others prefer to read and to remember words from dictionary. In addition, the students tend to browse from internet descriptive texts which have similar topic and study more by reading them. They believe it can help them to improve their organizational skill in writing descriptive text.

\section{Discussion}

\section{Students' Difficulties in Writing Descriptive Text}

Linguistics difficulties in writing descriptive text include the aspect regarding grammatical items and vocabulary mastery. The result showed that both of them are difficult to the students. Wehmeier (2005) pointed that grammar rules should be concerned more because the language learners will not understand composing text meaningfully and perhaps will result to the ambiguity. Vocabulary is difficult aspect in writing descriptive text. The problem focuses on remembering new vocabulary while the students do not have many vocabularies in their background knowledge.

The result of this research agrees with Rianto (2017) which found that many students have limited vocabulary list and poor choice of words. The problem in writing descriptive text could be happened because the students did not know many English vocabulary and they tend to put the words which were inappropriate in context. Rohmatilah (2014) stated the students are difficult to master vocabulary because the number of words that students need to learn is exceedingly large while the limitations of sources of information about words. In addition, words in English are complex which knowing a word involves much more than knowing its dictionary definition.

As in psychology difficulties, the students have low motivation and confidence in writing. There are two reasons for that. First, the students think that they do not have much experience in writing. The second, the students have mindset that writing is a difficult activity. They believe that they do not have the ability to produce a meaningful text by themselves (Yendri, 2019). Lack of practice might be the major reason in psychology 
difficulties. It is found in the feedback aspect almost all indicators were in positive. Fareed, Asraf \& Bilal (2016) added that the students must acquire component skills, practice integrating them, and know when to apply what they have learned over and over again.

As in cognitive difficulties, the students need to create, to coordinate, and to express ideas when dealing with writing activities. Rianto (2017) stated that it is necessary for some students to go slowly and take time to think about what they want to say before they write. Same line with it, Hanafi (2013) mentioned that the ability of the students to produce and organize their ideas will impact the quality of their final piece of writing. The students do not have difficulty in mechanic aspect. The students had problems with mechanics because the students were confused about writing a word spelling and they also had problems using punctuation especially for apostrophe and direct quotation. The students make misspelling and punctuation, so they couldn't improve the quality of their writing.

\section{The Most Dominant Difficulty Faced by the Students}

The most dominant difficulty faced by the students is about looking the idea of writing to the execution the idea. Organizing and developing ideas seems the bigger difficulties compare to other indicators. The result of this research in line with Yoandita (2019) which mentioned the students have difficulty in arranging the idea. The difficulties of the students in organizing the idea were incomplete idea and paragraph which had more than one idea. Students had difficulty organizing idea because some of the students were not able to arrange the idea well.

Same line with it, Husna, Zainil, \& Rozimela (2013) stated that in one paragraph, some students wrote several ideas, but the meaning of the paragraph was still unclear. The first problem relates to the development of ideas. The students are able to write a good sentence on the subject, but they are not able to organize it into a good paragraph. Second, the difficulty of organizing the ideas for writing a descriptive text. Many students are failed to organize the text well.

According to Aji (2016) the most complex of skill in writing is organization. The students find that it is difficult to develop idea in writing. This problem includes main idea, supporting idea, lack of vocabulary, grammar, lack of sources, arrangement, coherent and cohesion and diction. It is also pointed that there are many reasons students avoid writing. The major reasons are they struggle to organize and use mechanics of writing, they are inefficient in retrieving the vocabularies to express an idea, and the teachers are sometimes in situation which do not have enough training in teaching young learners.

Husna, Zainil, \& Rozimela (2013) explained that the students also need time for developing ideas and organizing them into a well paragraphs. They are not able to determine Linguists: Journal of Linguistics and Language Teaching Vol. 7, No. 1, July 2021 
topic, find supporting ideas, choose and arrange the sentences. It can be happened since so many writing processes need to be automatic, active working memory is critical. This can lead into poor vocabulary, many misspelled words, and grammar errors (Pratiwi, Syahrial, and Arasuli, 2012).

As the matter of fact, the key factors in writing are the organization of ideas. The writers can't really start writing because they don't have something in mind yet. The students face problems of exploring concepts and thinking about connecting with others. They have the problem of structuring the paragraph, topic development of a paragraph, structuring the whole discourse and a theme in a discourse, differentiating a topic and supporting ideas or generalizations and specific details.

\section{Students' Strategies to Overcome these Difficulties}

There are some strategies used by the students in order to overcome the difficulties they faced in writing. The strategies are based on of how they have they have the difficulties at first place. Hanafi (2013) explained that the factors causing difficulties in writing descriptive text are learners' background, teaching technique, and the learners' environment. It means that the students have different factors of why they might have the difficulties. It is necessary for the teachers to identify these factors before implementing the strategies to overcome them (Hayati, Afriani, \& Akbarjono, 2021).

The students believe that by learning over and over again, their vocabulary mastery has to be improved because writing requires more than just words and phrases being made. Students should be able to compose a connected sequence of terms and phrases that are grammatically and logically linked in order to be able to create a piece of writing in descriptive text, so that the intention they have in their mind will fit the intended readers. Azizah (2017) also argued that vocabulary mastery associates with writing descriptive text so the students need to improve their vocabulary mastery if they want to improve their writing skill.

According to Depari, Azwandi, and Syahrial (2017), it should be considered that if good writers can use words, they can effectively construct a composition so it is required for them to have the requisite vocabulary knowledge. Yunita (2010) also added that the students prefer to scan texts from the internet that have common subject matter and study more after reading them. They believe it can help them to improve their organizational and grammatical skill in writing. By looking to other examples from internet, the students can imitate and modify their writing into the better one. 


\section{CONCLUSION}

It can be concluded that there were five sub-aspect which is found in the interval positive difficult to the students which are grammatical items, vocabulary, learners' behavior, feedback, and organization. However, mechanic is found negative based on the result of questionnaire. Organization was the most difficult aspect for seventh grade students of SMP Sint Carolus Bengkulu. Finally, the strategies which the students choose to overcome these difficulties are mastering vocabulary and learning from other sources such as books or the internet.

Based on the conclusion above, there are some suggestions proposed in this study. (1) It is suggested for the English Teacher Organization or MGMP to conduct workshops and seminars regarding discussions or presentations of matter which is related to writing skills in hope to help the teachers overcoming the problem they faced in the classroom especially about students' difficulty in writing, (2) It is suggested for teacher to understand deeply about students' difficulties in writing, and (3) it is suggested to next researcher to conduct similar research in larger scope, and the correlation between students' difficulties and their ability in writing.

\section{REFERENCES}

Aji, H. 2016. Students' Difficulties and Strategies to Reinforce their Skill in Writing Descriptive Text at English Education Department of Universitas Muhammadiyah Yogyakarta. Unpublished thesis: Universitas Muhammadiyah Yogyakarta.

Azizah, Y. 2017. The Correlation Between Students' Vocabulary Mastery and Their Writing Ability in Descriptive Text ( A Study for the Seventh Grade Students of SMP Islam Sudirman 1 Bancak Semarang District in the Academic year of 2016/2017). Unpublished thesis: State Islamic Institute Salatiga.

Byrne, D. 1997. Teaching Writing Skills. London: Longman Inc.

Dastgeer, G. \& Afzal, M. T. 2015. Improving English writing skill: A case of Problem-Based learning. American Journal of Educational Research, 3(10), 1315-1319.

Depari, R.O., Azwandi, and Syahrial. 2017. The Effect of Picture Card Games to Students of Elementary School's Vocabulary Mastery. Journal of Applied Lingustic and Literature, 2(1), 1-12.

Fareed, M., Ashraf, A., \& Bilal, M. 2016. ESL Learners' Writing Skills: Problems, Factors and Suggestions. Journal of Education and Social Sciences. 4(1), 81-92.

Hanafi. 2013. An Analysis of Eleventh Graders' Difficulties in Writing Descriptive Text at MA Ni'matul Aziz Jelapat I Barito Kuala Academic Year 2017/2018. Unpublished thesis: State Islamic University of Antasari Banjarmasin.

Harmer, J. 2007. How to Teach English. Harlow: Pearson Education Limited.

Linguists: Journal of Linguistics and Language Teaching

Vol. 7, No. 1, July 2021 
Hayati, A. R., Afriani, Z. L., \& Akbarjono, A. (2021). Teacher's Teaching Strategies in EFL Class . Jadila: Journal of Development and Innovation in Language and Literature Education, 1(3), 330-341. https://doi.org/10.52690/jadila.v1i3.126

Husna, Zainil, \& Rozimela. 2013. An Analysis of Students' Writing Skill in Descriptive Text at Grade X1 IPA 1 of MAN 2 Padang. Journal English Language Teaching, 1(2), 116.

Milah, M. 2015. The Implementation of Problem Based Learning to Improve Writing Skill in Discussion Text (A Classroom Action Research at the Third Grade of MA NU 04 AlMa'arif Boja in the Academic Year of 2015/2016). Unpublished Thesis: Islamic State University of Walisongo.

Oshima, A \& A. Hogue. 1997. Introduction to Academic Writing, Second Edition. New York: Longman.

Pratiwi, K.D., Syahrial, and Arasuli. 2012. Students' Difficulties in Writing English (A Study at the Third Semester Students of English Education Program of UNIB in Academic Year 2011-2012). Unpublished thesis: Bengkulu University.

Rianto, A. 2017. A Case Study: Students' Difficulties in Writing Descriptive Text in the FirstYear Students at SMP Brawijaya Smart School (BSS) Malang. Unpublished thesis: Brawijaya University.

Rohmatillah. 2014. A study on students' difficulties in learning vocabulary. Jurnal Tardis Bahasa Inggris, 1(6), 69-86.

Sugiyono. 2012. Metode Penelitian Kuantitatif, Kualitatif, dan $R \& D$. Bandung: Alfabeta.

Swanson, L., Harris, K. R., \& Graham, S. 2003. Handbook of learning disabilities. NY: Guilford.

Tarigan, D. H. 1994. Menulis Sebagai Suatu Ketrampilan Bahasa. Bandung: Angkasa.

Wehmeier, S. 2005. Oxford Advanced Learning's Dictionary. Oxford: University Press.

Yendri, Y. 2019. Psychological Factors Affecting Undergraduate Students' Difficulties in Writing Thesis. Unpublished thesis: State Institute for Islamic Studies (IAIN) Bengkulu.

Yoandita, P. 2019. An Analysis of Students' Ability and Difficulties in Writing Descriptive Text. Journal of English Pedagogy, Linguistics, Literature, and Teaching, 7(1), 1-14.

Yunita, W. 2010. English Grammar Learning Strategies Preferably Used by the English Department Students of University of Bengkulu. Thesis. Graduate Program. State University of Padang. 